nucleotides encoding an amino-terminal polyhistidine tag. Sequence changes were introduced by site-directed mutagenesis using the Bio-Rad mutagenesis $\mathrm{kit}^{28}$ and confirmed by sequencing. The recombinant proteins were expressed in the bacterial strain BL21(DE3) after induction with IPTG $(0.5 \mathrm{mM})$ at room temperature and purified by $\mathrm{Ni}$ affinity chromatography.

T203F/T203Y imaging. Samples were prepared by the methods of ref. 21 from $10^{-10} \mathrm{M}$ solutions of protein diluted in $1 \mathrm{mg} \mathrm{ml}^{-1}$ BSA. Polyacrylamide gels ( $T=15 \%, C=5 \%$ without SDS) were prepared in $\mathrm{pH} 7$ phosphatebuffered saline doped with protein (here $T$ is the total concentration of monomer in g per $100 \mathrm{ml}, C$ is the wt $\%$ of total monomer which is crosslinker, and SDS indicates sodium dodecyl sulphate). The gel host provided pore sizes small enough for convenient (and complete) immobilization of each protein molecule, while maintaining its naturally fluorescent, native conformation ${ }^{21,29}$. Excitation with a $488-\mathrm{nm}$ laser $\left(100-2,000 \mathrm{~W} \mathrm{~cm}^{-2}\right.$ at the gel/coverslip interface) occurred in the total-internal-reflection geometry; the emission was imaged with a Nikon inverted microscope (250-nm resolution) with an Omega 535DF55 filter and a Princeton Instruments intensified frame transfer CCD (100 ms time resolution, $90 \mathrm{~s}$ collection time). Oxygen was not removed from samples for which data is shown, but samples prepared with $\sim 10 \mathrm{~min}$ helium bubbling showed similar on/off behaviour. 405-nm irradiation was produced by a $\mathrm{Hg}$ arc lamp with line filter through the epi-illumination port $\left(1 \mathrm{~W} \mathrm{~cm}^{-2}\right)$. The linear increase of detected photons as a function of laser intensity $\left(100-2,000 \mathrm{~W} \mathrm{~cm}^{-2}\right)$ indicated that saturation and multiphoton processes were negligible in these studies. Typical detected count rates of $5,000-6,000$ photons $\mathrm{s}^{-1}$ at $2,000 \mathrm{~W} \mathrm{~cm}^{-2}$ pumping intensity $(\sim 150,000$ excitations s$^{-1}$ ) were achieved, with most of the molecules emitting several millions of photons without irreversible bleaching.

Autocorrelation analysis. We define the autocorrelation function, $C(\tau)$, for discrete data points;

$$
C(\tau)=\sum_{t=0}^{N}(I(t)-\bar{I})(I(t+\tau)-\bar{I}) / \sum_{t=0}^{N}(I(t)-\bar{I})^{2}
$$

where $\bar{I}$ is the average intensity, $t$ is the time summed from 0 to $N 100$-ms intervals, and $I(t)$ is the time-dependent fluorescence intensity. Confidence limits were generated on the autocorrelations such that any values within the limits were consistent with zero ${ }^{30}$. Exponential fits of the autocorrelations were generated only for the statistically significant portions of the curves beyond the short time correlation spike arising from band-limited noise.

Received 8 April; accepted 17 June 1997

1. Moerner, W. E. \& Kador, L. Optical detection and spectroscopy of single molecules in a solid. Phys, Rev. Lett. 62, 2535-2538 (1989).

2. Orrit, M. \& Bernard, J. Single pentacene molecules detected by fluorescence excitation in a pterphenyl crystal. Phys. Rev. Lett. 65, 2716-2719 (1990).

Reilly, P. D. \& Skinner, J. L. Spectral diffusion of single molecule fluorescence: a probe of lowfrequency localized excitations in disordered crystals. Phys. Rev. Lett. 71, 4257-4260 (1993).

4. Moerner, W. E. Examining nanoenvironments in solids on the scale of a single, isolated molecule. Science 265, 46-53 (1994).

5. Barbara, P. F. \& Moerner, W. E. (eds) Single molecules and atoms. Acc. Chem. Res. 29, (1996).

6. Betzig, E. \& Chichester, R. J. Single molecules observed by near-field scanning optical microscopy. Science 262, 1422-1428 (1993)

7. Ambrose, W. P., Goodwin, P. M., Martin, J. C. \& Keller, R. A. Alterations of single molecule fluorescence lifetimes in near-field optical microscopy. Science 265, 364-367 (1994).

8. Nie, S., Chiu, D. T. \& Zare, R. N. Probing individual molecules with confocal fluorescence microscopy. Science 266, 1018-1021 (1994).

9. Trautman, J. K. \& Macklin, J. J. Time-resolved spectroscopy of single molecules using near-field and far-field optics. Chem. Phys. 205, 221-229 (1996).

10. Lu, H. P. \& Xie, X. S. Single-molecule spectral fluctuations at room temperature. Nature 385, 143-146 (1997).

11. Funatsu, T., Harada, Y., Tokunaga, M., Saito, K. \& Yanagida, T. Imaging of single fluorescent molecules and individual ATP turnovers by single myosin molecules in aqueous solution. Nature 374, 555-559 (1995).

12. Vale, R. D. et al. Direct observation of single kinesin molecules moving along microtubules. Nature 380, 451-453 (1996).

13. Schmidt, T., Schutz, G. J., Baumgartner, W., Gruber, H. J. \& Schindler, H. Imaging of single molecule diffusion. Proc. Natl Acad. Sci. USA 93, 2926-2929 (1996).

14. Basché, T., Moerner, W. E., Orrit, M. \& Wild, U. P. (eds) Single Molecule Optical Detection, Imaging, and Spectroscopy (Verlag-Chemie, Munich, 1997).

15. Heim, R., Prasher, D. C. \& Tsien, R. Y. Wavelength mutations and posttranslational autoxidation of green fluorescent protein. Proc. Natl Acad. Sci. USA 91, 12501-12504 (1994).

16. Cubitt, A. B. et al. Understanding, improving and using green fluorescent proteins. Trends Biochem Sci. 20, 448-455 (1995).

17. Chattoraj, M., King, B. A., Bublitz, G. U. \& Boxer, S. G. Ultra-fast excited state dynamics in green fluorescent protein: Multiple states and protein transfer. Proc. Natl Acad. Sci USA 93, 8362-8367 (1996).

18. Brejc, K. et al. Structural basis for dual excitation and photoisomerization of the Aequorea victoria green fluorescent protein. Proc. Natl. Acad. USA 94, 2306-2322 (1997).

19. Ormo, M. et al. Crystal structure of the Aequorea victoria green fluorescent protein. Science 273, 1392 1395 (1996).
20. Yang, F., Moss, L. G. \& Phillips, J. G. N. The molecular structure of green fluorescent protein. Nature Biotechnol. 14, 1246-1251 (1996).

21. Dickson, R. M., Norris, D. J., Tzeng, Y.-L. \& Moerner, W. E. Three dimensional imaging of single molecules in pores of poly(acrylamide) gels. Science 274, 966-969 (1996).

22. Moerner, W. E. et al. Optical probing of single molecules of terrylene in a Shpolskii matrix-a twostate single-molecule switch. J. Phys. Chem. 98, 7382-7389 (1994).

23. Stuart, J. A., Tallent, J. R., Tan, E. H. L. \& Birge, R. R. in Sixth Biennial IEEE Intl Nonvolatile Memory Technol. Conf. Proc. 35-51 (IEEE, Albuquerque, NM, 1996).

24. Sakmann, B. \& Neher, E. Single Channel Recording (Plenum, New York, 1995).

25. Yokoe, H. \& Meyer, T. Spatial dynamics of GFP-tagged proteins investigated by local fluorescence enhancement. Nature Biotechnol. 14, 1252-1256 (1996).

26. Irie, M. in Photo-reactive Materials for Ultrahigh Density Optical Memory (ed. Irie, M.) 1-12 (Elsevier Science, Amsterdam, 1994).

27. Parthenopoulos, D. A. \& Rentzepis, P. M. Three-dimensional optical storage memory. Science $\mathbf{2 4 5}$, 843-845 (1989).

28. Kunkel, T. A., Roberts, J. D. \& Zakour, R. A. Rapid and efficient site-specific mutagenesis without phenotypic selection. Meth. Enzymol. 154, 367-382 (1987).

29. Fawcett, J. S. \& Morris, C. J. O. R. Molecular-sieve chromatography of proteins on granulated polyacrylamide gels. Separat. Sci. 1, 9-26 (1966).

30. Box, G. E. P. \& Jenkins, G. M. Time Series Analysis Forecasting and Control (Holden-Day, San Francisco, 1970)

Acknowledgements. We thank L. S. B. Goldstein and S. Kummer for discussions. This work was supported by the NSF.

Correspondence and requests for materials should be addressed to W.E.M. (e-mail:wmoerner@ucsd.edu).

\section{The soil production function and landscape equilibrium}

\section{Arjun M. Heimsath ${ }^{\star}$, William E. Dietrich* Kunihiko Nishiizumi $\uparrow$ \& Robert C. Finkel $\ddagger$}

* Department of Geology and Geophysics, 301 McCone Hall, University of California, Berkeley, California 94720-4767, USA

$\dagger$ Space Sciences Laboratory, University of California, Berkeley, California 94720-7450, USA

$\$$ Center for Accelerator Mass Spectrometry, Lawrence Livermore National Laboratory, Livermore, California 94550, USA

Hilly and mountainous landscapes are partially to completely covered with soil under a wide range of erosion and uplift rates, bedrock type and climate. For soil to persist it must be replenished at a rate equal to or greater than that of erosion. Although it has been assumed for over 100 years that bedrock disintegration into erodable soil declines with increasing soil mantle thickness ${ }^{1-9}$, no field data have shown this relationship. Here we apply two independent field methods for determining soil production rates to hillslopes in northern California. First, we show that hillslope curvature (a surrogate for soil production ${ }^{7}$ ) varies inversely with soil depth. Second, we calculate an exponential decline of soil production rates with increasing soil depth from measurements of the in situ produced cosmogenic ${ }^{10} \mathrm{Be}$ and ${ }^{26} \mathrm{Al}$ concentrations in bedrock sampled under soils of different depths. Results from both methods agree well and yield the first empirical soil production function. We also illustrate how our methods can determine whether a landscape is in morphological equilibrium or not.

Soil thickness depends on the balance between production and erosion of soil (Fig. 1). We define soil to be distinct colluvial material, lacking relict rock structure and derived from underlying bedrock. The mechanical disruption that destroys rock structure and lowers the soil-bedrock interface may be due to processes that are biotic (for example, burrowing and three throw) ${ }^{7}$ or abiotic (for example, dissolution-induced collapse, freeze-thaw, and shear deformation). Downslope soil transport can occur by mass wasting, overland flow, and biogenic disturbance. We focus on diffusive transport where the sediment flux, $\tilde{q}_{\mathrm{s}}$, is proportional to slope, $\nabla z$, such that $\tilde{q}_{\mathrm{s}}=-K \nabla z$; here $K$ is equivalent to a diffusion coefficient with dimensions (length) $)^{2}$ (time) ${ }^{-1}$. This relationship was articulated by Davis ${ }^{10}$ and Gilbert ${ }^{11}$ and has been extensively applied in 
models of landscape evolution ${ }^{2,5,7,12-14}$. It seems to be appropriate for biogenic transport ${ }^{7,15}$ and soil creep ${ }^{16}$.

If we use this relationship in the mass conservation equation for soil thickness, $h$ (Fig. 1),

$$
\rho_{\mathrm{s}} \frac{\partial h}{\partial t}=-\rho_{\mathrm{r}} \frac{\partial e}{\partial t}-\nabla \cdot \rho_{\mathrm{s}} \tilde{q}_{\mathrm{s}}
$$

and assume steady-state soil thickness (that is, $\partial h / \partial t=0$ ), then soil production $-(\partial e / \partial t)$ is given by

$$
\frac{\partial e}{\partial t}=-\frac{\rho_{\mathrm{s}}}{\rho_{\mathrm{r}}} K \nabla^{2} z
$$

where $\rho_{\mathrm{s}}$ and $\rho_{\mathrm{r}}$ are soil and rock bulk densities, $z$ is ground surface elevation, $e$ is the elevation of the bedrock-soil interface and $t$ is time. Under such conditions, soil production should depend on hillslope curvature, $\nabla^{2} z$. Furthermore, if $K$ is assumed to be spatially and temporally constant, we can use topographic curvature as a surrogate for soil production rates ${ }^{7}$. The form of the soil production function (that is, $-\partial e / \partial t=f(h)$ ) can then be defined with field measurements of curvature and depth. We note that, according to equation (2), spatial variation of curvature across diffusion-dominated regions of the landscape indicates spatial variation in local production rates and that the landscape is not in equilibrium.

We can test directly this depth-dependent soil production rate by adapting the cosmogenic nuclide method of determining erosion rates $^{17,18}$. If we assume that bedrock conversion to soil reaches a steady state under a constant soil thickness, $h$ (and the soil bulk density remains constant), then the concentration of the cosmogenic radionuclide, $C$ (in atoms $\mathrm{g}^{-1}$ ), in the bedrock at the soilbedrock interface is

$$
C=P(h, \theta)\left(\frac{1}{\lambda+\frac{\rho_{\mathrm{r}} \epsilon}{\Lambda}}\right)
$$

where $P(h, \theta)$ is the nuclide production rate (in atoms $\mathrm{g}^{-1} \mathrm{yr}^{-1}$ ) at depth $h$ and slope $\theta, \Lambda$ is the mean attenuation length $\left(\sim 165 \mathrm{~g} \mathrm{~cm}^{-2}\right), \lambda$ is the decay constant of the radionuclide $\left(\lambda=\ln 2 / t_{1 / 2}\right)$, and $\epsilon\left(\right.$ in $\left.\mathrm{cm} \mathrm{yr}^{-1}\right)$ is $-\partial \mathrm{e} / \partial \mathrm{t}$ in equation (1). Equation (3) is of the same form as that used by others to calculate the erosion rate of bedrock (in which case, $h$ and $\theta$ equal zero) ${ }^{17,19}$. We solve for soil production rates as:

$$
\epsilon=-\frac{\partial e}{\partial t}=\frac{\Lambda}{\rho_{\mathrm{r}}}\left(\frac{P(h, \theta)}{C}\right)
$$

The production rates of ${ }^{10} \mathrm{Be}$ and ${ }^{26} \mathrm{Al}$ in quartz are known ${ }^{20,21}$, and we measure bulk densities and soil depths. The soil production function is determined by measuring the nuclide concentrations in bedrock sampled under different soil depths, calculating soil production rates, and plotting them against soil depth.

Equations (2) and (4) provide two independent methods to test the hypothesis that soil production rates decline with increasing soil thickness. The first relies entirely on field observations and can be applied only in areas where slope-dependent mass transport is dominant. The second does not require slope-dependent transport. Both require local soil thickness to be, on average, constant with time. The validity of this assumption will vary considerably depending on the field location.

We focused our study on small ridges ('noses') in Tennessee Valley, Marin County, California, a field site used for extensive geomorphical research ${ }^{7,22-25}$. Intensely sheared thrust sheets of greenstone, greywacke sandstone and chert, typical of the Jurassic-Cretaceous Franciscan assemblage in the Marin Headlands terrane, underlie the field area $^{26}$. The area receives an average annual rainfall of $760 \mathrm{~mm}$ (ref. 27) and was grazed before $1972^{7}$. There is no evidence that Pleistocene climate variation caused

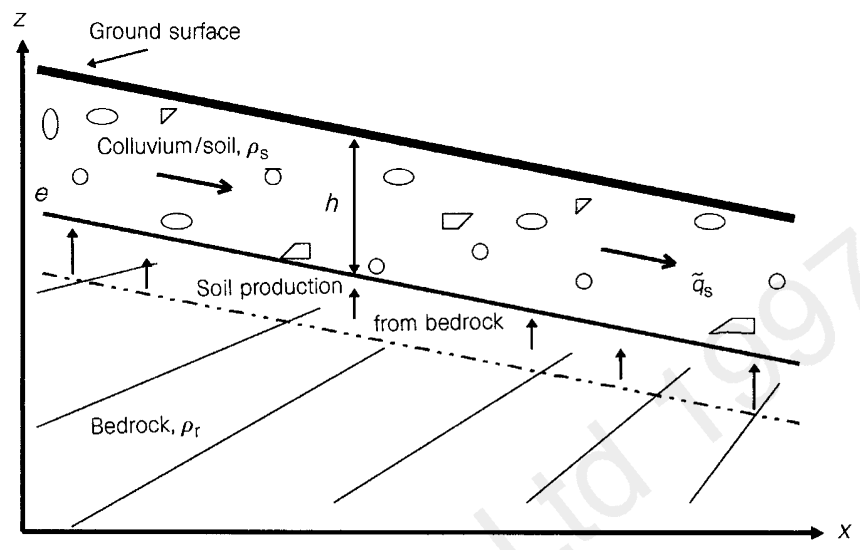

Figure 1 The conservation of mass equation for soil thickness $h$ (equation (1)) states that the change in soil mass with time, $t$, is equal to the conversion of bedrock to soil due to lowering of the bedrock-soil interface less the divergence of transported soil mass. The area shown between the base of the soil at elevatione and the dashed line is the amount of bedrock that would be converted to soil over some specified time interval. In our study area, mass transport, $\tilde{q}_{\mathrm{s}}$, of the entire active layer of soil is caused primarily by biogenic processes acting on an inclined surface. Here $\rho_{\mathrm{s}}$ and $\rho_{\mathrm{r}}$ are the densities of soil and bedrock, respectively. Note that $z=e+h$, a bedrock-fixed coordinate system not accounting for tectonic influences on absolute elevation, and $h$ is much less than the landscape elevation scale. (Modified from Dietrich et $a l^{7}{ }^{7}$ )

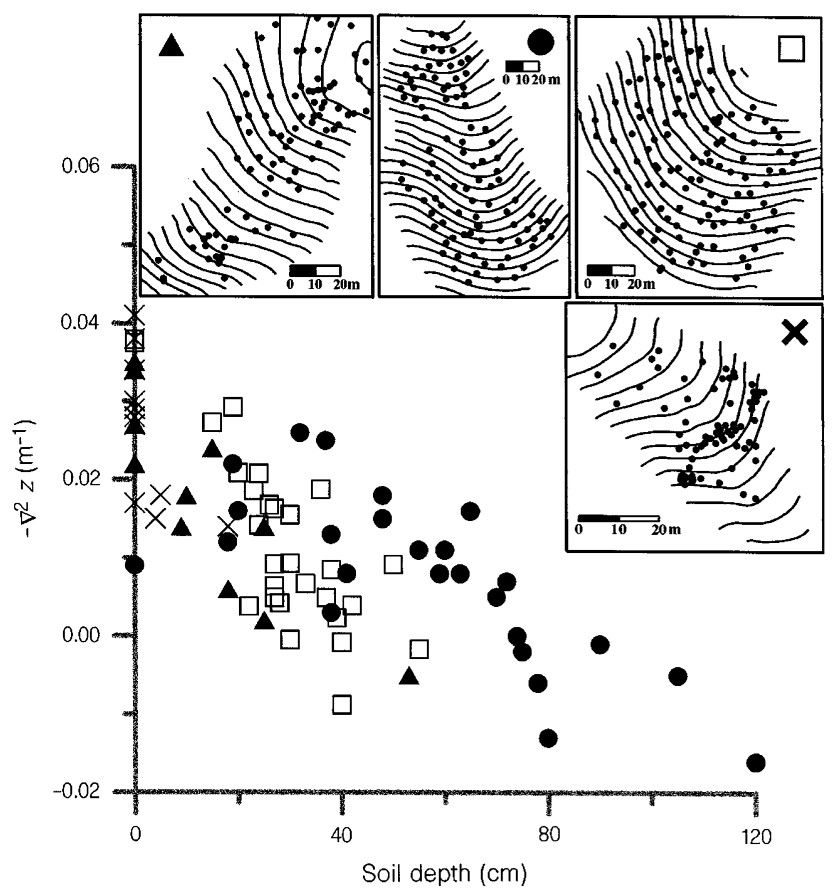

Figure 2 Plot of negative hillslope curvature, $-\nabla^{2} z$, against local soil depth for four distinct small ridges (inset maps drawn with 2-m contour intervals) in Tennessee Valley, Marin County, California ( $\left.37.9^{\circ} \mathrm{N}, 122.6^{\circ} \mathrm{W}\right)$. The large upper corner symbol on each inset map corresponds to the $-\nabla^{2} z$ values plotted for the respective ridge and shows ridge locations on the landscape shown in Fig. 3 left inset. Dots on the inset maps are depth measurement locations. Each ridge was surveyed with 1$3 \mathrm{~m}$ resolution and gridded using a Krigging interpolation scheme. Curvature was calculated at each point using the interpolated elevations of the eight nearest grid neighbours. We found distinct soil-bedrock boundaries on each ridge. Soil depth was measured to the bottom of the colluvial layer, either by digging pits or by averaging several auger holes. 
dramatically fluctuating hillslope erosion rates or processes, although net sediment storage in valleys and landslide frequency in unchannelled valleys (hollows) may have varied ${ }^{23,28}$. Although there may have been partial Pleistocene forest cover, there is no evidence of a Holocene forest. The vegetation is a mixture of coastal grassland and scrub. In colluvium-mantled hollows, exfiltrating subsurface flow and rain on saturated areas generate extended areas of saturation overland flow ${ }^{25}$. The soil mantle varies in thickness across the landscape and is typically an organic-rich, stony loam with weak to no horizon development. Soil production seems to be due primarily to biogenic disruption of weathered bedrock ${ }^{7}$. Soil and rock fragments from pocket gopher (Thomomys bottae) burrows abound, and soil pits show burrowing through the typically abrupt soil-bedrock boundary. Burrowing is also the primary mechanism for downslope soil transport $\mathrm{t}^{22}$ and effective diffusivities have been quantified ${ }^{7,16,23}$. Landsliding is mostly confined to steep hollows of thick colluvial deposits ${ }^{24,25}$.

We selected four small ridges, each underlain by greywacke, for this study (Figs 2 and Fig. 3 left inset). The high topographic divergence of these small ridges and the modest slopes ensured that soil transport by landsliding has been insignificant. Figure 2 shows that curvature declines with increasing soil thickness, as predicted if curvature is a surrogate for soil production and soil production decreases with soil thickness. The large variance is expected because: (1) biogenic soil production causes short-term variation in local thickness; and (2) bedrock heterogeneity in resistance to weathering and mechanical disruption by biota leads to local variability in the curvature-thickness relationship. In general, strongly convex areas have thin soils and weakly convex areas have thicker soils.

We sampled bedrock from the base of the soil column and from exposed bedrock on three of the four surveyed small ridges and at other locations for cosmogenic nuclide analyses (Fig. 3 left inset). The samples reflect the range of soil thickness measured on these ridges. Figure 3 main figure shows that soil production rates, calculated from both ${ }^{10} \mathrm{Be}$ and ${ }^{26} \mathrm{Al}$ concentrations, decline exponentially with increasing soil depth. Erosion rates of prominent, isolated bedrock outcrops varied with rock type, with chert eroding the slowest. The average erosion rates we measured from stream sediments ${ }^{29,30}$ for two steep tributaries (labelled 1 and 2 in Fig. 3 left inset) were close to the maximum soil production rates (Table 1). Figure 3 right inset shows good agreement between the two methods even though no parameters were adjusted to match these data.

Two general production laws have been proposed ${ }^{31}$. An exponential decline of soil production with increasing soil depth was assumed to simulate the decrease in effectiveness of such mechan- ical processes as freeze-thaw ${ }^{3}$ or biogenic disturbance ${ }^{7}$. A complex, bell-shaped polynomial function follows the intuition that maximum soil production occurs under a thin layer of soil ${ }^{3,8}$. Dietrich et $a .^{7}$ point out, however, that soil depths less than the peak are unstable (perturbations in thickness would strip the soil to bedrock) and found field-based agreement with an exponential production function. Although our data cannot reject the polynomial function, they do show that the peak production rate would occur under nearzero soil depth and would make little difference to modelling ${ }^{7}$.

An important assumption in our analysis is steady-state local soil depth during soil production and transport. This assumption is justified in several ways. There is no evidence for shallow landsliding or erosion by overland flow on the convex regions we studied. Soil production by burrowing tends not to alter local soil thickness dramatically during burrowing. Numerical experiments by Dietrich et $a .^{7}$ show that diffusion-dominated ridges quickly (in a few thousand years) reach local steady-state soil thickness. Topographic change on such ridges is slow and changes in soil production or transport with Pleistocene-Holocene climate change would have adjusted local soil thickness early in the Holocene. Last, the observed ${ }^{10} \mathrm{Be}$ and ${ }^{26} \mathrm{Al}$ concentrations imply erosion rates that would result in steady-state radionuclide concentrations in a few tens of thousands of years.

In contrast to the local steady-state condition for soils on the small ridges, our observations indicate that the landscape may be slowly changing morphologically. We find both the thinnest soils and the highest production rates on ridge crests, indicating the greatest lowering rates. Individual ridges with their different degrees of curvature may also be lowering at different rates (Fig. 2). Erosion rate varies with lithology and solitary outcrops are eroding slower than the surrounding landscape. Basin-wide erosion rates in the two primary tributaries of our catchment suggest that erosion is higher in these steep regions than on the gentler, lower-elevation small ridges; Dietrich et al. ${ }^{7}$ observed that nearly all shallow landslide scars in the catchment are in those regions. The northern tributary basin may be lowering more rapidly than the southern one (Fig. 3). Although local, short-term variation in lowering rates can be expected on landscapes, our results suggest that Tennessee Valley is undergoing systematic morphological change. We also observe that such deviation from dynamic equilibrium can be inferred from landscape form, as proposed by Dietrich et al. ${ }^{7}$ For the divergent ridge crests, or ridges where diffusive transport processes are dominant, spatial variation in curvature implies variation in lowering rates. We note however, that soil depth variation alone does not indicate disequilibrium. Ahnert ${ }^{9}$ showed that constant-form

\begin{tabular}{|c|c|c|c|c|c|c|c|c|c|}
\hline Sample & $\begin{array}{l}\text { Depth } \\
(\mathrm{cm})\end{array}$ & $\begin{array}{r}\text { Slope } \\
\text { (deg) }\end{array}$ & $\begin{array}{l}\text { Elev. } \\
\text { (m) }\end{array}$ & $\begin{array}{l}\text { Quartz } \\
\text { wt (g) }\end{array}$ & $\begin{array}{c}{ }^{26} \mathrm{Al} \\
\left(10^{6} \text { atoms g }\right. \\
\end{array}$ & 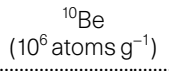 & ${ }^{26} \mathrm{Al} /{ }^{10} \mathrm{Be}$ & $h$-slope factor & $\begin{array}{c}-\partial e / \partial t \\
\left(\mathrm{~m} \mathrm{Myr}^{-1}\right)\end{array}$ \\
\hline TV-2 & 0 & 8 & 135 & 40.65 & $0.600 \pm 0.101$ & $0.115 \pm 0.006$ & $5.22 \pm 0.92$ & 1 & $39 \pm 8$ \\
\hline TV-3 & 16 & 10 & 120 & 40.06 & $0.447 \pm 0.054$ & $0.108 \pm 0.007$ & $4.15 \pm 0.56$ & 0.87 & $47 \pm 15$ \\
\hline TV-4 & 0 & 15 & 275 & 42.68 & $1.132 \pm 0.078$ & $0.248 \pm 0.010$ & $4.55 \pm 0.37$ & 0.98 & $20 \pm 5$ \\
\hline TV-5 & 0 & 0 & 275 & 40.22 & $1.433 \pm 0.121$ & $0.351 \pm 0.017$ & $4.08 \pm 0.40$ & 1.00 & $15 \pm 4$ \\
\hline TV-6 & 35 & 15 & 105 & 42.03 & $1.104 \pm 0.050$ & $0.195 \pm 0.008$ & $5.65 \pm 0.34$ & 0.69 & $26 \pm 3$ \\
\hline TV-7 & 58 & 20 & 100 & 42.58 & $1.446 \pm 0.061$ & $0.229 \pm 0.016$ & $6.32 \pm 0.52$ & 0.52 & $21 \pm 3$ \\
\hline TV-10 & 51 & 17 & 115 & 40.71 & $0.939 \pm 0.104$ & $0.171 \pm 0.011$ & $5.49 \pm 0.71$ & 0.59 & $25 \pm 4$ \\
\hline TV-11 & 0 & 21 & 120 & 32.39 & $0.234 \pm 0.035$ & $0.040 \pm 0.005$ & $5.92 \pm 1.20$ & 0.98 & $107 \pm 23$ \\
\hline TV-12 & 30 & 15 & 116 & 40.56 & $0.394 \pm 0.091$ & $0.074 \pm 0.006$ & $5.28 \pm 1.30$ & 0.72 & $60 \pm 16$ \\
\hline TV-13 & 49 & 18 & 140 & 40.03 & $1.060 \pm 0.112$ & $0.151 \pm 0.013$ & $7.03 \pm 0.95$ & 0.61 & $26 \pm 5$ \\
\hline TV-15 & 20 & 15 & 135 & 40.33 & $0.563 \pm 0.055$ & $0.083 \pm 0.006$ & $6.77 \pm 0.83$ & 0.85 & $48 \pm 8$ \\
\hline TV-16 & 35 & 20 & 133 & 45.05 & $0.741 \pm 0.076$ & $0.134 \pm 0.007$ & $5.54 \pm 0.64$ & 0.68 & $33 \pm 5$ \\
\hline TV-17 & 60 & 25 & 133 & 52.57 & $0.914 \pm 0.093$ & $0.161 \pm 0.015$ & $5.68 \pm 0.77$ & 0.54 & $27 \pm 5$ \\
\hline TV-23 & 0 & 15 & 137 & 40.28 & $0.260 \pm 0.051$ & $0.050 \pm 0.005$ & $5.16 \pm 1.14$ & 0.98 & $91 \pm 24$ \\
\hline Creek1a & NA & NA & 110 & 51.50 & $0.414 \pm 0.053$ & $0.063 \pm 0.005$ & $6.61 \pm 1.00$ & 1 & $64 \pm 12$ \\
\hline Creek1b & NA & NA & 110 & 40.22 & $0.366 \pm 0.050$ & $0.063 \pm 0.006$ & $5.81 \pm 0.95$ & 1 & $66 \pm 13$ \\
\hline Creek2 & NA & NA & 110 & 58.22 & $0.239 \pm 0.049$ & $0.041 \pm 0.005$ & $5.87 \pm 1.37$ & 1 & $102 \pm 25$ \\
\hline
\end{tabular}

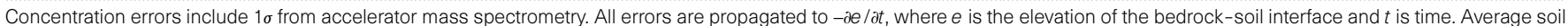

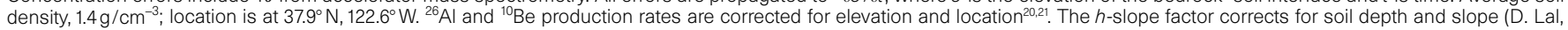
personal communication). NA, not available. 


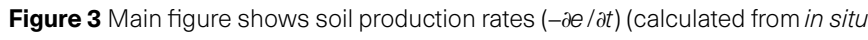
produced cosmogenic ${ }^{10} \mathrm{Be}$ and ${ }^{26} \mathrm{Al}$ in bedrock samples) versus measured soil depths $h$. Al and Be were chemically separated and purified ${ }^{32}$ after chemically separating quartz and adding Be carrier; we measured ${ }^{10} \mathrm{Be}$ and ${ }^{26} \mathrm{Al}$ concentrations at the Lawrence Livermore National Laboratory accelerator mass spectrometry (AMS) facility ${ }^{33}$. We normalized the measured ratios to the $I C N^{10} \mathrm{Be}$ and the NBS ${ }^{26} \mathrm{Al}$ standards (Table 1). We plot the average calculated rate from both nuclides. Left inset, map showing cosmogenic nuclide sample locations (open triangles) in Tennessee Valley, Marin County, California. Samples (plotted in the main figure as filled circles) were taken from bedrock exposed at the ground surface or the soil-bedrock boundary revealed at the base of pits dug across three of the four ridges shown in Fig. 2. The exponential fit to these data is $-(\partial e / \partial t)=(77 \pm 9) e^{((-0.023 \pm 0.003 \mathrm{~h})}$. Other outcrops (plotted in the main figure as upside-down triangles were sampled from a large, $\sim 25-\mathrm{m}$ relief, greenstone (TV4), a 3-m-high bedded chert (TV-5) at the top of sub-basin 2, and from outcropping greywacke (TV-2) at one of the surveyed hillslope ridge crests. Two different creek sediment samples ( 1 and 2, filled diamonds, plotted to left of $y$ axis in the main figure) were taken to estimate average erosion rates ${ }^{29,30}$. Right inset, plot showing an overlay of the nuclide-based results with the soil production rates calculated from $-\nabla^{2} z$ values (Fig. 2) using a regional diffusivity of $50 \mathrm{~cm}^{2} \mathrm{yr}^{-1}$ (refs 7,16, 23) and average $\rho_{\mathrm{s}} / \rho_{\mathrm{r}}=0.5$. In three cases, TV-3, TV-4 and TV-5, the observed ${ }^{26} \mathrm{Al} /{ }^{10} \mathrm{Be}$ ratio differs significantly from the expected production ratio of 6.0. These disparities may indicate either that the samples have experienced complex exposure histories or that some analytical problem exists. Here we interpret these samples with our simple exposure model, expressing the disparity between the ${ }^{26} \mathrm{Al}$ and the ${ }^{10} \mathrm{Be}$ results with the large uncertainty in the soil production/erosion estimates for these samples. This uncertainty does not alter the inference that the bedrock outcrops are eroding more slowly than other parts of the landscape. Only TV-3 is used in determining the soil production curve and, in fact, deleting it would not change the function.

hillslopes with spatially variable soil depths develop when the soil production function varies with underlying lithology.

The peak soil-production rate determines under what tectonic and erosional environments bedrock will emerge or become dominant across a landscape. If the soil production function varies with climate, bedrock and biota, then landscapes under similar tectonic regimes can have different morphology, ranging from fully soil-mantled rounded hills to bedrock cliffs. Our two independent methods provide a means to define empirically soil production functions for different rock types and climates. This should facilitate exploring the role of geology and climate in landscape evolution.

Received 28 January; accepted 12 June 1997

1. Gilbert, G. K. Report on the Geology of the Henry Mountains (US Geol. Surv., Washington DC, 1877). 2. Culling, W. E. H. Soil creep and the development of hillside slopes. J. Geol. 71, 127-161 (1963).

3. Ahnert, F. in L'evolution des Versants (ed. Macar, P.) 23-41 (Univ. Liege, 1967).

4. Tucker, G. E. \& Slingerland, R. Predicting sediment flux from fold and thrust belts. Basin Res. 8, 329349 (1996).

5. Anderson, R. S. \& Humphrey, N. F. in Quantitative Dynamic Stratigraphy (ed. Cross, T.) 349-361 (Prentice Hall, Englewood Cliffs, New Jersey, 1989).

6. Rosenbloom, N. A. \& Anderson, R. S. Hillslope and channel evolution in a marine terraced landscape, Santa Cruz, California. J. Geophys. Res. 99, 14013-14029 (1994).

7. Dietrich, W. E., Reiss, R., Hsu, M.-L. \& Montgomery, D. R. A process-based model for colluvial soil depth and shallow landsliding using digital elevation data. Hydrol. Proc. 9, 383-400 (1995).

8. Carson, M. A. \& Kirkby, M. J. Hillslope Form and Process (Cambridge Univ. Press, New York, 1972).

9. Ahnert, F. Approaches to dynamic equilibrium in theoretical simulations of slope development. Earth Surf. Proc. Landforms 12, 3-15 (1987).

10. Davis, W. M. The convex profile of badland divides. Sciences 20, 245 (1892)

11. Gilbert, G. K. The convexity of hilltops. J. Geol. 17, 344-350 (1909).

12. Kirkby, M. J. Hillslope Process-response Models Based on the Continuity Equation 15-30 (Spec. Publ. 3, Inst. Brit. Geogr., London, 1971).

13. Koons, P. O. The topographic evolution of collisional mountain belts; a numerical look at the Southern Alps, New Zealand. Am. J. Sci. 289, 1041-1069 (1989).

14. Howard, A. D. A detachment-limited model of drainage basin evolution. Wat. Resour. Res. 30, $2261-$ 2285 (1994).

15. Reneau, S. L. \& Dietrich, W. E. Erosion rates in the southern Oregon Coast Range: evidence for an equilibrium between hillslope erosion and sediment yield. Earth Surf. Proc. Landforms 16, 307-322 (1991).

16. McKean, J. A., Dietrich, W. E., Finkel, R. C., Southon, J. R. \& Caffee, M. W. Quantification of soil

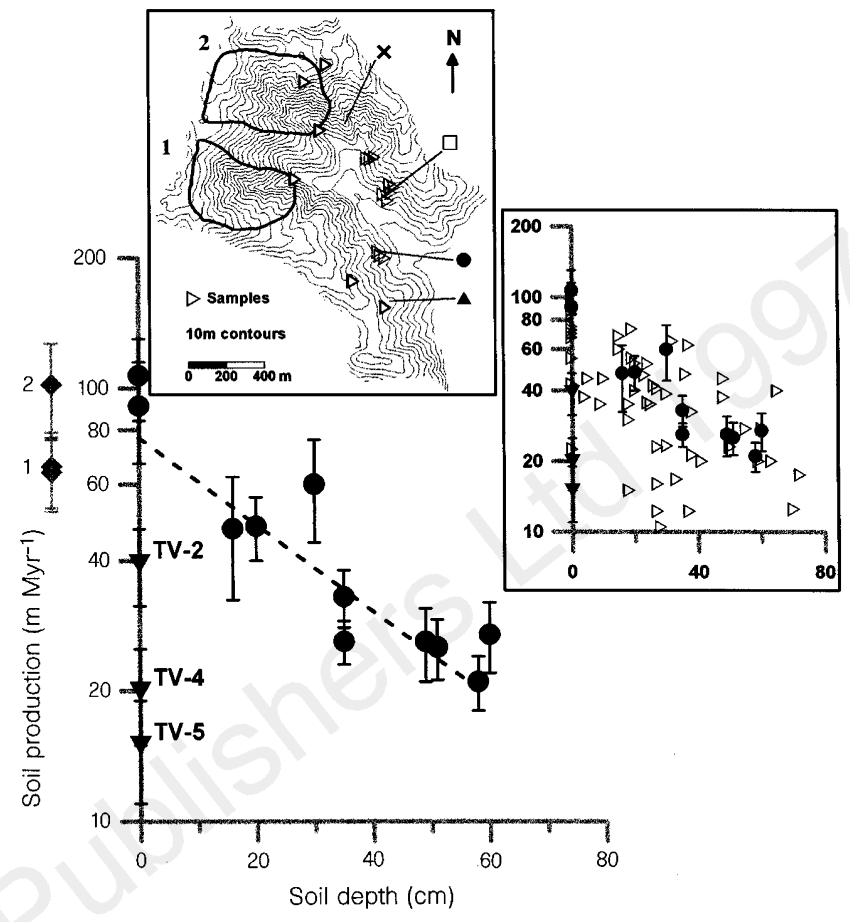

production and downslope creep rates from cosmogenic ${ }^{10} \mathrm{Be}$ accumulations on a hillslope profile. Geology 21, 343-346 (1993).

17. Lal, D. \& Arnold, J. R. Tracing quartz through the environment. Proc. Indian Acad. Sci. (Earth Planet. Sci.) 94, 1-5 (1985).

18. Nishiizumi, K., Lal, D., Klein, J., Middleton, R. \& Arnold, J. R. Production of ${ }^{10} \mathrm{Be}$ and ${ }^{26} \mathrm{Al}$ by cosmic rays in terrestrial quartz in situ and implications for erosion rates. Nature 319, 134-136 (1986).

19. Nishiizumi, K. et al. Cosmic ray produced ${ }^{10} \mathrm{Be}$ and ${ }^{26} \mathrm{Al}$ in Antarctic rocks: exposure and erosion history. Earth Planet. Sci. Lett. 104, 440-454 (1991).

20. Lal, D. Cosmic ray labeling of erosion surfaces: in situ nuclide production rates and erosion models. Earth Planet. Sci. Lett 104, 424-439 (1991).

21. Nishiizumi, K. et al. Cosmic ray production rates of ${ }^{10} \mathrm{Be}$ and ${ }^{26} \mathrm{Al}$ in quartz from glacially polished rocks. J. Geophys. Res. 94, 17907-17915 (1989).

22. Black, T. A. \& Montgomery, D. R. Sediment transport by burrowing animals, Marin County, California. Earth Surf. Proc. Landforms 16, 163-172 (1991).

23. Reneau, S. L. Depositional and erosional history of hollows; application to landslide location and frequency, long-term erosion rates, and the effects of climatic change. Thesis, Univ. California, Berkeley (1988).

24. Dietrich, W. E., Wilson, C. J., Montgomery, D. R., McKean, J. \& Bauer, R. Erosion thresholds and land surface morphology. Geology 20, 675-679 (1992).

25. Dietrich, W. E., Wilson, C. J., Montgomery, D. R. \& McKean, J. Analysis of erosion thresholds, channel networks, and landscape morphology using a digital terrain model. J. Geol. 101, 259-278 (1993).

26. Wahrhaftig, C. Structure of the Marin headlands block, California: a progress report. Franciscan Geol. N. California 43, 31-50 (1984).

27. Rantz, S. E. Average annual precipitation and runoff in north coastal California. (Hydrol. Atlas 298, scale 1:1,000,000, US Geol. Surv. Menlo Park, 1968).

28. Rypins, S., Reneau, S. L., Byrne, R. \& Montgomery, D. R. Palynologic and geomorphic evidence for environmental change during the Pleistocene-Holocene transition at Point Reyes Peninsula, central coastal California. Quat. Res. 32, 72-87 (1989)

29. Granger, D. E., Kirchner, J. W. \& Finkel, R. Spatially averaged long-term erosion rates measured from in situ-produced cosmogenic nuclides in alluvial sediment. J. Geol. 104, 249-257 (1996).

30. Bierman, P. \& Steig, E. J. Estimating rates of denudation using cosmogenic isotope abundances in sediment. Earth Surf. Proc. Landforms 21, 125-139 (1996).

31. Cox, N. J. On the relationship between bedrock lowering and regolith thickness. Earth Surf. Proc. Landforms 5, 271-274 (1980).

32. Kohl, C. P. \& Nishiizumi, K. Chemical isolation of quartz for measurement of in-situ-produced cosmogenic nuclides. Geochim. Cosmochim. Acta 56, 3585-3587 (1992).

33. Davis, J. C. et al. LLNL/UC AMS facility and research program. Nucl. Instrum. Meth. B 52, 269-272 (1990).

Acknowledgements. We thank K. Heimsath and L. Cossey for field and laboratory assistance; D. DePaolo for laboratory space; D. Lal for suggestions; and the Golden Gate National Recreation Area for access to our study site. We thank P. Bierman and A. Howard for comments on the manuscript. This work was supported by Cal Space, IGPP-LLNL, NSF, NASA, DOE and a Switzer Environmental fellowship.

Correspondence and requests for materials should be addressed to A.M.H. (e-mail: arjun@moray. berkeley.edu). 